Journal of Islamic Medicine

Vol 4(1) (2020), Pages 40-45

e-ISSN: 2550-0074

Original research article

\title{
PENGARUH TEKNIK BOLA PERSALINAN (BIRTHING BALL) \\ TERHADAP PENURUNAN BAGIAN BAWAH JANIN PADA IBU \\ PRIMIGRAVIDA INPARTU KALA I FASE AKTIF DI PMB IKE SRI \\ KEC. BULUWANG KAB. MALANG
}

\author{
${ }^{1}$ Anik Purwati dan ${ }^{1}$ Tut Rayani A \\ ${ }^{1}$ Politeknik Kesehatan RS dr. Soepraoen Malang \\ *Corresponding author \\ Email: anikasyda@gmail.com
}

\begin{tabular}{l}
\hline \\
\hline Kata kunci : \\
Ibu primigravida inpartu \\
kala I fase aktif \\
Teknik bola persalinan \\
(birthing ball) \\
Penurunan bagian bawah \\
janin \\
\hline
\end{tabular}

\section{A bstrak}

Latarbelakang : Birthing ball adalah terapi fisik atau latihan sederhana yang menggunakan bola. Istilah birthing ball berasal dari kata birth ball dapat diartikan ketika latihan dengan menggunakan bola diterapkan untuk ibu hamil, ibu melahirkan dan ibu pasca melahirkan. Manfaat dari pemakaian birthing ball ini adalah meningkatkan aliran darah ke rahim, plasenta dan bayi, meredakan tekanan dan dapat memberikan rasa nyaman untuk lutut dan pergelangan kaki, memberikan kontra-tekanan pada perineum dan paha tegak. Postur ini bekerja dengan gravitasi yang akan mendorong turunnya bayi ke dalam dasar panggul sehingga mempercepat proses persalinan. Selain itu, menggunakan birthing ball dapat membantu menyeleraskan bayi selama kehamilan dan persalinan menyeimbangkan tubuh pada bola untuk membantu memperkuat punggung, juga membantu menyelaraskan bayi dalam persiapan untuk kelahiran. Tujuan : Untuk mengetahui pengaruh pemberian teknik bola persalinan (briting ball) terhadap penurunan bagian bawah janin pada ibu primigravida inpartu kala I fase aktif. Metode Penelitian : Desain penelitian ini menggunakan pre eksperimen dengan pre test-post test design. Populasi berjumlah 24 orang dan jumlah sampel 16 responden yang sesuai kriteria inklusi yaitu ibu inpartu primigravida sesuai dengan teknik purposive sampling tanpa ada kelompok kontrol. Proses pengumpulan data menggunakan lembar observasi dan lembar standar prosedur operasional (SPO) untuk pemberian teknik bola persalinan (brithing ball) dan lembar observasi untuk mengetahui penurunan bagian bawah janin ke dalam rongga panggul. Hasil : Berdasarkan uji statistik Wilcoxon dengan menggunakan SPSS Versi 20 didapatkan hasil $p$ value $=.000$ dengan nilai signifikan $\alpha=0,05$, karena $p<0,05$ $(.000<0,05)$ maka dapat disimpulkan bahwa HI diterima artinya ada pengaruh pemberian teknik bola persalinan terhadap penurunan bagian bawah janin pada ibu inpartu kala I fase aktif. Kesimpulan : Ada pengaruh pemberian teknik bola persalinan (brithing ball) terhadap penurunan bagian bawah janin pada ibu inpartu kala I fase aktif. 


\section{LATAR BELAKANG}

Proses kemajuan persalinan kala I fase aktif pada primigravida dipengaruhi oleh dilatasi servik dan penurunan kepala janin ke dalam dasar panggul. Nyeri persalinan disebabkan oleh adanya kontraksi uterus yang berlangsung secara regular dengan intensitas yang semakin lama semakin kuat dan semakin sering (adekuat).

Proses kemajuan persalinan kala I fase aktif pada primigravida dipengaruhi oleh dilatasi servik dan penurunan kepala janin ke dasar panggul. Nyeri persalinan disebabkan oleh kontraksi yang berlangsung secara regular dengan intensitas yang semakin lama semakin kuat dan semakin sering. Birthball memiliki arti bola lahir yang dapat digunakan pada ibu inpartu kala I ke posisi yang biasa membantu kemajuan persalinan. Adapun keuntungan dari pemakaian birthball ini adalah meningkatkan aliran darah ke rahim, plasenta dan bayi, meredakan tekanan dan dapat meningkatkan ouilet panggul sebanyak $30 \%$, serta dapat memberikan rasa nyaman pada lutut dan pergelangan kaki, memberikan kontra-tekanan pada perineum dan paha, bekerja dengan gravitasi yang mendorong turunnya bayi sehingga mempercepat proses persalinan (Aprilia, 2011).

\section{METODE}

Penelitian ini menggunakan desain pre eksperimen dengan pendekatan pre test-post test design tanpa ada kelompok kontrol. Sebelum pemberian intervensi dilakukan pemeriksaan dalam pada ibu inpartu kala I fase aktif untuk mengetahui bagian bawah janin berada dibidang Hodge, setelah diketahui posisi awal dari penurunan bagian bawah janin kemudian diberi perlakuan teknik birthing ball selama 15-30 menit setelah itu dilakukan pemeriksaan dalam ulang setiap 4 jam sekali untuk menilai kemajuan persalinan dan salah satunya menilai penurunan bagian bawah janin masuk ke dalam rongga panggul. Dalam penelitian ini peneliti ingin mengetahui pengaruh teknik birthing ball terhadap penurunan bagian bawah janin pada ibu primigravida inpartu kala I fase aktif di PMB Ike Sri Kec. Bululawang Kab. Malang.

\section{HASIL DAN PEMBAHASAN \\ Hasil Penelitian}

Penelitian dilakukan pada bulan Januari 2019 di PMB Ny. Ike Sri Kec. Bululawang Kab. Malang. Kelompok perlakuan yaitu ibu bersalin primigravida dengan menggunakan teknik bitthng ball berjumlah 16 responden. Berikut ini disajikan hasil penelitian secara keseluruhan:

\section{Data umum responden}

\section{Tabel 1. Karakteristik responden}

\begin{tabular}{llcc}
\hline No & $\begin{array}{l}\text { Karakteristik } \\
\text { responden }\end{array}$ & $\begin{array}{c}\text { Frekuensi } \\
\text { (f) }\end{array}$ & $\begin{array}{c}\text { Presentase } \\
\text { (\%) }\end{array}$ \\
\hline $\mathbf{1}$ & Usia & & \\
& ×20 Tahun & 4 & 25 \\
& 21- 35 Tahun & 12 & 75 \\
& >35 Tahun & 0 & 0 \\
\hline $\mathbf{2}$ & Pendidikan & & \\
& SD & 4 & 25 \\
& SMP & 8 & 50 \\
& SMA & 4 & 25 \\
& Perguruan & 0 & 0 \\
& Tinggi & & \\
\hline $\mathbf{3}$ & Pekerjaan & & \\
& IRT & 14 & 88 \\
& Swasta & 2 & 12 \\
& Pegawai Negeri & 0 & 0 \\
\hline & Total & 16 & 100 \\
\hline
\end{tabular}

Berdasarkan tabel 1 di atas dapat dijelaskan bahwa usia responden sebagian besar 
responden berusia 21-35 tahun sebanyak 12 orang $(75 \%)$, Pendidikan reponden setengahnya 8 orang $(50 \%)$ berpendidikan SMP dan pekerjaan responden hampir seluruhnya sebanyak 14 orang $(88 \%)$ bekerja sebagai ibu rumah.

Karakteristik Responden berdasarkan Penurunan bagian bawah janin sebelum Pemberian teknik Bola Persalinan (Brithing Ball).

Tabel 2. Distribusi frekuensi tentang penurunan bagian bawah janin

\begin{tabular}{clcc}
\hline No & $\begin{array}{l}\text { Penurunan } \\
\text { Bagian } \\
\text { Bawah janin }\end{array}$ & $\begin{array}{c}\text { Frekuensi } \\
\text { (f) }\end{array}$ & $\begin{array}{c}\text { Presentase } \\
(\%)\end{array}$ \\
\hline 1 & Hodge I & 1 & 6 \\
2 & Hodge II & 11 & 69 \\
3 & Hodge III & 4 & 25 \\
4 & Hodge IV & 0 & 0 \\
& Jumlah & 16 & 100 \\
\hline
\end{tabular}

Berdasarkan tabel 2 di atas menunjukkan bahwa hampir seluruhnya sebanyak 11 orang $(69 \%)$ mengalami penurunan bagian bawah janin di Hodge II dan sebagian kecil responden sebanyak 1 orang $(6 \%)$ di Hodge I.

Karakteristik Responden berdasarkan Penurunan bagian bawah janin setelah Pemberian teknik Bola Persalinan (Brithing Ball)

Tabel 3. Distribusi Frekuensi Tentang Penurunan Bagian Bawah Janin

\begin{tabular}{clcc}
\hline & $\begin{array}{l}\text { Penurunan } \\
\text { Bagian }\end{array}$ & $\begin{array}{c}\text { Frekuensi } \\
\text { (f) }\end{array}$ & $\begin{array}{c}\text { Presentase } \\
(\%)\end{array}$ \\
\hline 1 & Bawah & & \\
2 & Hodge I & 0 & 0 \\
3 & Hodge II & 0 & 0 \\
4 & Hodge III & 10 & 63 \\
& Jodge IV & 6 & 37 \\
\hline
\end{tabular}

Berdasarkan tabel 3 di atas menunjukkan bahwa hampir seluruhnya sebanyak 10 orang $(63 \%)$ mengalami penurunan bagian bawah janin di Hodge III dan sebagian kecil responden sebanyak 6 orang $(37 \%)$ di Hodge IV.

Pengaruh Pemberian teknik Bola Persalinan (brithing ball) Terhadap Penurunan bagian bawah janin pada ibu primigravida Kala I Fase Akif di PMB Ike Sri Kec. Bululawang Kab. Malang.

Tabel 4. Tabulasi silang tentang pengaruh pemberian teknik bola persalinan terhadap penurunan bagian bawah janin.

\begin{tabular}{|c|c|c|c|c|c|}
\hline \multirow[t]{2}{*}{$\begin{array}{c}\text { Teknik } \\
\text { Brithing } \\
\text { Ball } \\
\end{array}$} & \multicolumn{4}{|c|}{$\begin{array}{c}\text { Penurunan Bagian Bawah } \\
\text { Janin }\end{array}$} & \multirow[t]{2}{*}{ Total } \\
\hline & $\mathrm{H} \mathrm{I}$ & H II & H III & H IV & \\
\hline \multirow[t]{2}{*}{ Sebelum } & 1 & 11 & 4 & 0 & 16 \\
\hline & $6 \%$ & $69 \%$ & $25 \%$ & $0 \%$ & $100 \%$ \\
\hline \multirow[t]{2}{*}{ Setelah } & 0 & 0 & 10 & 6 & 16 \\
\hline & $0 \%$ & $0 \%$ & $63 \%$ & $37 \%$ & $100 \%$ \\
\hline
\end{tabular}

Berdasarkan tabel 4 di atas menunjukkan bahwa dari 16 responden sebelum pemberian teknik Bola Persalinan (brithing ball) hampir seluruhnya sebanyak 11 orang $(69 \%)$ mengalami penurunan bagian bawah janin pada HII dan Setelah pemberian teknik Bola Persalinan (brithing ball) sebagian besar mengalami penurunan kepala bagian bawah janin pada hodge III sebanyak 10 orang $(63 \%)$ dan 6 orang $(37 \%)$ mengalami penurunan di Hodge IV.

Berdasarkan uji statistik Wilcoxon dengan menggunakan SPSS Versi 20 didapatkan hasil $\mathrm{p}$ value $=.000$ dengan nilai signifikan $\alpha=0,05$, karena $\mathrm{p}<0,05(.000<$ $0,05)$ maka dapat disimpulkan bahwa $\mathrm{HI}$ diterima artinya ada pengaruh pemberian 
teknik bola persalinan (brithing ball) terhadap penurunan bagian bawah janin dan intensitas nyeri pada ibu inpartu kala I fase aktif.

\section{Pembahasan}

Berdasarkan data hasil penelitian tentang penurunan bagian bawah janin sebelum pemberian teknik bola persalinan (brithing ball) yaitu dari 16 responden hampir seluruhnya sebanyak 11 orang (69\%) mengalami penurunan bagian bawah janin di Hodge II dan sebagian kecil responden sebanyak 1 orang $(6 \%)$ di Hodge I.

Sedangkan penurunan bagian bawah janin setelah pemberian teknik bola persalinan (brithing ball) didapatkan data hampir seluruhnya sebanyak 10 orang (63\%) mengalami penurunan bagian bawah janin di Hodge III dan sebagian kecil responden sebanyak 6 orang (37\%) di Hodge IV.

Menurut teori Aprilia (2011) dalam proses persalinan, bola (brithing ball) bisa menjadi media/alat untuk digunakan dalam berbagai posisi. Duduk di atas bola sambil mendorong sepeti ayunan atau membuat gerakan memutar panggul dapat membantu proses penurunan janin ke dalam dasar panggul. Bola memberikan dukungan pada perineum tanpa banyak tekanan dan membantu mempercepat proses persalinan. Selain itu keuntungan posisi duduk tegak di atas bola dapat meningkatkan aliran darah ke rahim, plasenta dan bayi, postur ini membuat gaya gravitasi mendorong turunnya kepala bayi.

Sedangkan menurut penelitian dari Indrayani (2016) menyatakan bahwa pada posisi ibu juga sangat berpengaruh terhadap adaptasi anatomi dan fisiologi persalinan. Posisi tegak juga memberikan beberapa keuntungan. Merubah posisi memberikan kenyamanan, membuat rasa letih berkurang, dan melancarkan sirkulasi darah. Pada posisi tegak meliputi duduk di atas gym ball (pelvic rocking), berdiri, jongkok, berjalan. Posisi tegak memungkinkan untuk penurunan bagian terbawah janin. Birthing ball juga memiliki manfaat lain diantaranya dapat mengurangi angka kejadian kala I memanjang, mempercepat pembukaan serviks, merangsang kontraksi uterus, memperlebar diameter panggul serta mempercepat penurunan kepala janin.

Dalam proses persalinan, bola bisa menjadi alat penting, dan dapat digunakan dalam berbagai posisi. Duduk tegak di atas bola sambil mendorong seperti melakukan ayunan atau membuat gerakan memutar panggul, dapat membantu proses penurunan janin. Bola memberikan dukungan pada perineum tanpa banyak tekanan dan membantu menjaga janin sejajar di panggul. Posisi duduk di atas bola, diasumsikan mirip dengan berjongkok membuka panggul, sehingga membantu mempercepat proses persalinan. Gerakan lembut yang dilakukan di atas bola sangat mengurangi rasa sakit saat kontraksi. Dengan bola ditempatkan di tempat tidur, klien bisa berdiri dan bersandar dengan nyaman di atas bola, mendorong dan mengayunkan panggul untuk mobilisasi (Hypno birthing, 2014).

Penggunaan bola kelahiran selama persalinan mencegah ibu dalam posisi terlentang secara terus menerus. Bola kelahiran mendorong ibu dalam posisi tegak baik itu dalam posisi duduk, berlutut atau berdiri. Posisi ini berguna untuk membuka rongga panggul dan mendorong bayi turun. Perubahan posisi selama persalinan dapat merubah bentuk dan ukuran rongga panggul yang akan membantu kepala bayi turun ke posisi 
optimal selama kala I persalinan dan membantu bayi rotasi dan turun pada kala II persalinan (Maurenne. 2005).

\section{KESIMPULAN DAN SARAN}

Berdasarkan hasil penelitian dari 16 responden sebelum pemberian perlakuan dengan menggunakan teknik bola persalinan (brithing ball) menunjukkan bahwa hampir seluruhnya sebanyak 11 orang $(69 \%)$ mengalami penurunan bagian bawah janin di Hodge II dan sebagian kecil responden sebanyak 1 orang $(6 \%)$ di Hodge I.

Berdasarkan hasil penelitian dari 16 responden setelah pemberian perlakuan dengan menggunakan teknik bola persalinan (brithing ball) hampir seluruhnya sebanyak 10 orang (63\%) mengalami penurunan bagian bawah janin di Hodge III dan sebagian kecil responden sebanyak 6 orang (37\%) di Hodge IV.

Pengaruh Pemberian teknik Bola Persalinan (Brithing Ball) Terhadap Penurunan bagian bawah janin pada ibu primigravida Kala I Fase Akif di PMB Ike Sri Kec. Bululawang Kab. Malang.

Berdasarkan hasil uji statistik Wilcoxon dengan menggunakan SPSS Versi 20 didapatkan hasil $\mathrm{p}$ value $=.001$ dengan nilai signifikan $\alpha=0,05$, karena $\mathrm{p}<0,05(.001<$ $0,05)$ maka dapat disimpulkan bahwa $\mathrm{HI}$ diterima artinya ada Pengaruh Pemberian Teknik bola persalinan (Brithing Ball) terhadap penurunan bagian bawah janin dan intensitas nyeri pada ibu inpartu Kala I Fase Aktif.

Dengan hasil penelitian ini dapat memberikan gambaran tentang Pemberian Teknik bola persalinan (Brithing Ball) terhadap penurunan bagian bawah janin pada ibu inpartu Kala I Fase Aktif, sehingga diharapkan ibu- ibu lebih kooperatif dalam menghadapi proses persalinan.

Dengan hasil penelitian ini diharapkan dapat dijadikan acuan untuk memberikan asuhan kebidanan dengan menggunakan teknik bola persalinan (birthing ball) pada ibu inpartu sebagai alternatif untuk membantu proses penurunan bagian bawah janin ke dalam dasar panggul.

\section{DAFTAR PUSTAKA}

Arikunto. 2010. Prosedur Penelitian Suatu Pendekatan Praktik Edisi Revisi. Jakarta: Rineka Cipta.

Dewi Cendika \& Indarwati. 2010. Panduan Pintar Hamil \& Melahirkan, Jakarta: Wahyu Media.

Erty, C.2017. Afektifitas Pelvic rocking Terhadap Lama Persalinan, Dilatasi Serviks dan Penurunan Kepala Janin Pada Ibu Primigravida. Prosiding Seminar Nasional Kebidanan.

Hidayat. 2010. Pengukuran Motivasi. http://drsuparyanto. Blogspot. Com/2010/2009/konsep-motivasi. html. Diakses pada tanggal 24 Februari 2011.

Hypno-birthing. 2014. Pelatihan Basic Hypnotis \& Hypno-birthing.

Indrayani. 2016. update Asuhan Persalinan dan Bayi Baru Lahir. Jakarta.

Jenny J. S. Sondakh, 2013. Asuhan Kebidanan Persalinan \& Bayi Baru Lahir.

Mochtar, Rustam. 2003. Sinopsis Obstetry Jilid I. Jakarta: ECG.

Notoatmodjo, Sukidjo. 2010. Metode Penelitian Kesehatan. Jakarta: Rineka Cipta

Nursalam. 2013. Konsep Penerapan Metodelogi Penelitian Ilmu Keperawatan. Jakarta: Salemba Medika.

Prawirohardjo, Sarwono. 2008. Buku Acuan Nasional Pelayanan Kesehatan Maternal Dan Neonatal. Jakarta: Yayasan Bina Pustaka. 
Sugiyono, 2010. Statistik untuk Penelitian. Bandung: Alfabeta.

Siwi Walyani, Elisabeth dan Purwoastuti, Endang. 2016. Asuhan Kebidanan Persalinan \& Bayi Baru Lahir. Yogjakarta: PT.Pustaka Baru.

Saifudin, Abdul Bari. 2008. Pelayanan Kesehatan Maternal Neonatal. Jakarta: Yayasan Bina Pustaka Sarwono.

Purwati, Anik Dan Veronika Widia Trilupi, Maria. 2018. Asuhan Kebidanan Pada Ibu Bersalin \& Bayi Baru Lahir. Nganjuk: CV. Adjie Media Nusantara.

Maurenne. 2005. Birthing balt; http : //mynaturaI child birth. Orglbirthing baIl/ diunduh tanggal 21 Desember 2013. 